\title{
Analisis Kesalahan Berbahasa Arab Pada Percakapan Sehari Hari di Pondok Modern Asy-Syifa Balikpapan
}

\author{
Muhammad Thohir \\ UIN Sunan Ampel Surabaya \\ Email: muhammadthohir@uinsby.ac.id \\ Juliantika Imannisya \\ UIN Sunan Ampel Surabaya \\ Email: juliantikaimannisya03@gmail.com
}

\section{ملخص}

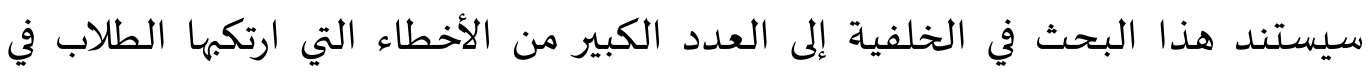

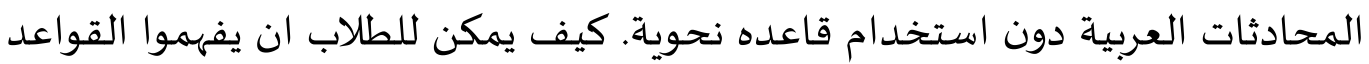
حتى يتمكن الطلاب من الحديث بأسلوب الكلام اليومي. والغرض من هذا العاد البحث هو معرفه مدي ضخامة الأخطاء الناطقة بالعربية ومعرفه العوامل التي تسبب تحليل العابل الأخطاء اللغوية النحوية في الكلام عند طلاب بمعهد العصرى بالكبابان. وكانت أساليب البحث

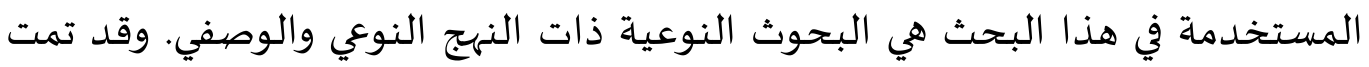

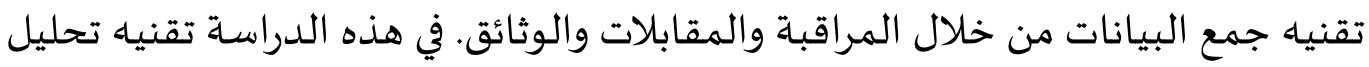
البيانات المستخدمة هو الحد من البيانات ، وعرض البيانات ، وسحب الاستنتاج. نتائج هذا البحث تحدث خطاء وتعيين العوامل الصحيحة تحليل الأخطاء اللغوية النحوية في

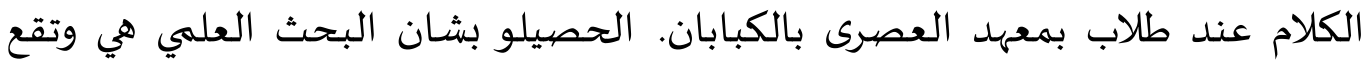

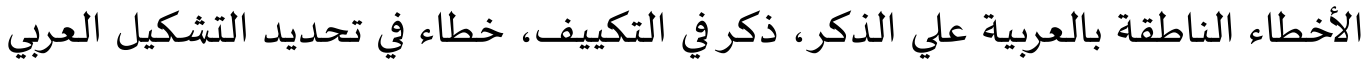

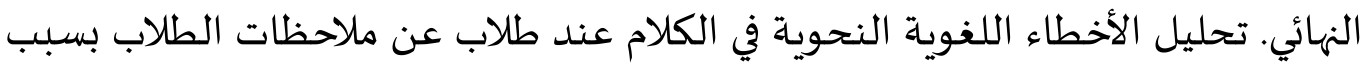

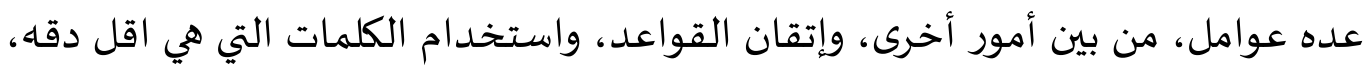

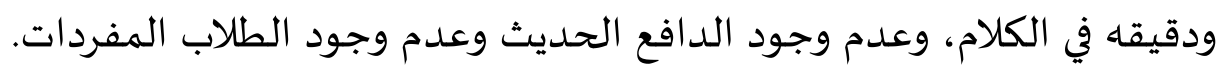

\section{الكلمة الرئيسية : تحليل الأخطاء، اللغة العربية، المهارة الكلام}

Abstrak

Latar belakang penelitian ini akan didasarkan pada banyaknya kesalahan yang dilakukan siswa dalam percakapan bahasa Arab tanpa menggunakan aturan gramatikal. Bagaimana siswa memahami tata bahasa sehingga siswa dapat berbicara dalam gaya bertutur sehari-hari. Tujuan dari penelitian ini adalah 
untuk mengetahui sejauh mana besarnya kesalahan berbicara bahasa Arab dan untuk mengetahui faktor-faktor yang menyebabkan terjadinya analisis kesalahan tata bahasa dalam tuturan pada mahasiswa Institut Al-Asry Kebaban. Metode penelitian yang digunakan dalam penelitian ini adalah penelitian kualitatif dengan pendekatan kualitatif dan deskriptif. Teknik pengumpulan data dilakukan melalui observasi, wawancara dan dokumen. Dalam penelitian ini teknik analisis data yang digunakan adalah reduksi data, penyajian data, dan penarikan kesimpulan. Hasil penelitian ini menginduksi kesalahan dan mengidentifikasi faktor yang benar Analisis kesalahan linguistik gramatikal pada tuturan mahasiswa Al Asry Institute Kabban. Hasil penelitian ilmiah ini adalah adanya kesalahan berbahasa arab pada saat dzikir, disebutkan dalam pengkondisian, kesalahan dalam penentuan komposisi akhir arab. Menganalisis kesalahan gramatikal linguistik dalam tuturan siswa tentang hasil observasi siswa karena beberapa faktor antara lain penguasaan tata bahasa, penggunaan kata yang kurang tepat, ketepatan dalam tuturan, kurangnya motivasi berbicara dan kurangnya kosa kata siswa.

\section{Kata Kunci: Analisis Kesalahan, Bahasa Arab, Keterampilan Berbicara}

\section{Abstract}

The background of this study will be based on the many mistakes student in Arabic conversations without using grammatical rules. How students understand grammar so that students can speak in everyday speech styles. The purpose of this study was to determine the extent of the error in speaking Arabic and to determine the factors that cause the analysis of grammatical errors in speech among students of the Al-Asry Kebaban Institute. The research method used in this research is qualitative research with a qualitative and descriptive approach. Data collection techniques are carried out through observation, interviews, and documents. In this study, the data analysis techniques used were data reduction, data presentation, and conclusion drawing. The results of this study induce errors and identify the correct factors. Analysis of grammatical linguistic errors in the speech of $\mathrm{Al}$ Asry Institute Kabban students. The result of this scientific research is that there is an error in Arabic during dhikr, mentioned in the conditioning, an error in determining the final Arabic composition. Analyzing linguistic grammatical errors in students' speech regarding the results of student observations due to several factors, including grammar mastery, inappropriate word use, accuracy in speech, lack of motivation to speak, and lack of student vocabulary.

Keywords: Error Analysis, Arabic Language, Speaking Skills

\section{Pendahuluan}


Bahasa merupakan sistem lambang-lambang (simbol-simbol) berupa bunyi yang digunakan oleh sekelompok orang atau masyarakat tertentu untuk berkomunikasi dan berinteraksi. ${ }^{1}$ Bahasa juga dapat diartikan sebagai alat komunikasi yang terorganisasi dalam bentuk satuan-satuan, seperti kata, kelompok kata, dan kalimat yang diungkapkan baik secara lisan maupun tulis. ${ }^{2}$ Kita bisa mengerti bahwasanya semua definisi ini ialah apabila bahasa telah dikatakan sebagai bunyi karena bahasa itu berupa suara yang dapat didengarkan, jika bahasa itu lafadh-lafadh yang memiliki makna, jika bahasa dikatakan sebagai ungkapan kalimat karena memang bahasa itu tersusun berupa ungkapan kalimat yang merupakan rangkaian kata, dan jika bahasa itu dikatakan sebagai aturan-aturan yang berupa rumus-rumus karena bahasa itu memiliki aturan-aturan yang mengikatnya dalam bentuk rumus-rumus sehingga makna atau maksud kalimat dalam suatu bahasa itu bisa difahami oleh orang yang mendengarkannya. ${ }^{3}$

Bahasa Arab adalah salah satu bahasa yang juga dpelajari di indonesia, dan menjadi sebagai bahasa kedua. Bahwasanya bahasa kedua, bahasa Arab ini masih dianggap sulit. Meskipun mayoritas penduduk di indonesia ini adalah muslim/ muslimah dan kitab sucinya ialah Al-Qur'an yang berbasis bahasa Arab. Kesulitan menggunakan bahasa Arab dan bahasa indonesia ini merupakan dua bahasa yang tidak sama. ${ }^{4}$ Dengan demikian peranan bahasa Arab di samping ini sebagai alat komunikasi sesama manusia juga komunikasi manusia yang beriman dengan Allah SWT, yang terwujud dalam bentuk sholat, doa-doa, dan sebagainya.

Dapat kita ketahui di indonesia, bahasa Arab ini sudah menjadi pelajaran dalam kegiatan belajar mengajar, mulai dari tingkat SD/MI sampai ke perguruan tinggi. Seperti halnya di pondok modern Asy-Syifa Balikpapan yang saat ini terkenal dengan ke moderenan nya, salah satunya dalam berbicara bahasa Arab dan bahasa inggris. Karena di

${ }^{1}$ Ahmad Izzan, Metodologi Pembelajaran Bahasa Arab. (Bandung: Humaniora, 2015). Hal. 2.

2 Tri Wiratno dan Riyadi Santosa, "Bahasa,Fungsi Bahasa, dan Konteks Sosial", dalam Modul Pengantar Linguistik Umum,Bing4214/Modul,1. Hal. 1-2.

2.

${ }^{3}$ Fathur Rohman, Metodologi Pembelajaran Bahasa Arab. (Jatim: Madani,2015). Hal.

4 Wa Muna, Metodologi Pembelajaran Bahasa Arab. (Yogyakarta: Penerbit Teras, 2011). Hal. 42. 
pondok modern Asy-Syifa ini seluruh santriwan dan santriwati diwajibkan untuk berbicara bahasa Arab dan bahasa inggris dalam kesehariannya. Dilihat itu sangat bagus, akan tetapi akan lebih baik lagi jika apa yang dibicarakan

dengan bahasa Arab dan bahasa inggris menggunakan tata cara bahasa sesuai dengan kaidahnya. Adapun yg penulis inginkan, penulis ingin agar pondok modern asy-syifa ini tidak hanya pandai dalam berbicara bahasa Arab dan bahasa inggris saja tetapi berbicara sesuai dengan kaidah-kaidahnya.

Oleh karena itu, orang yang akan mempelajari sumber-sumber ajaran agama islam ini harus memahami secara baik terkait bahasa Arab yang meliputi beberapa aspek. Diantara aspek bahasa Arab yang sangat penting dan menjadi faktor utama adalah ilmu shorof dan ilmu nahwu. Orang yang tidak menguasai ilmu shorof dan ilmu nahwu ini akan memahami buku-buku bahasa Arab secara tidak benar. Demikian pula orang yang ingin menerjemahkan buku bahasa Arab ke dalam bahasa indonesia ini harus bisa memahami kedua ilmu secara baik agar tidak mengalami banyak kesalahan. ${ }^{5}$

Kesalahan berbahasa dapat terjadi pada situasi atau bidang-bidang tertentu terutama pada pemakaian bahasa yang tidak hanya mengutamakan faktor komunikatif sebagai hasil akhir dalam aktivitas berbahasa, tetapi juga memperhatikan kaidah berbahasanya. ${ }^{6}$ Analisis kesalahan berbahasa ini bertujuan untuk mendeskripsikan kesalahan santri dalam mempelajari bahasa kedua. Hasil dari analisis ini kemudian dijadikan acuan bagi para guru untuk lebih menekankan aspek kebahasaan tertentu yang merupakan wilayah terjadinya kesalahan siswa. Akan tetapi kesalahan yang terjadi pada siswa tidak hanya disebabkan oleh faktor dari dalam diri siswa saja melainkan juga berasal dari berbagai faktor eksternal. Salah satunya adalah kesalahan yang disebabkan oleh kesalahan guru dalam memberikan pengetahuan kepada siswa.

Secara umum tujuan pembelajaran bahasa Arab di Indonesia adalah agar para siswa mampu menggunakan bahasa secara aktif. Aktif yaitu

5 Azyumardi Azra, Esei-Esei intelektual muslim dan Pendidikan Islam. (Jakarta: Wacana Ilmu, 1999). Hal. 33.

${ }^{6}$ Gio Muhammad Johan dan Yusrawati JR Simatupang, Analisis Kesalahan Berbahasa Indonesia Secara Sintaktis dalam Proses Diskusi, dalam Jurnal Visipena no.2, Vol.8, 2017

El-Ibtikar Vol 9 No 2 Desember 2020 
kemampuan berkomunikasi baik secara lisan, yaitu dapat berbicara dengan orang lain maupun secara tertulis seperti membuat karangan. Kemampuan berbahasa aktif dalam hal ini komunikasi lisan, maka yang harus dilakukan adalah penguasaan kosakata sebanyak mungkin, serta praktek dari penguasaan kosakata tersebut dalam sebuah lingkungan berbahasa yang mendukung. ${ }^{7}$

Berdasarkan dalam pengamatan peneliti, masalah dalam mempelajari bahasa Arab sampai sekarang ini masih banyak terjadi dikalangan para santri. Seperti halnya masalah yang terjadi dimadrasah maupun di pondok pesantren. Hal ini telah di respon dari para santri yang merasakan langsung masalah-masalah dalam pendidikan bahasa Arab tingkat ini. Masalah tersebut tidak lagi bisa dianggap sebagai masalah yang dapat dimaklumi begitu saja seperti ketika di pondok pesantren. Untuk itu dari masalah-masalah yang ada akan mendapatkan perhatian serius. Yang dimaksud dari masalah-masalah tersebut salah satu problematikanya adalah rendahnya kemampuan berbicara dalam kaidah akibat kurangnya menguasai kosa kata dan tidak melatih diri dalam berkomunikasi. Padahal di pondok tersebut sudah mempelajari nahwu dan shorof, namun pada kenyataannya masih saja terdapat santri yang belum mampu berbahasa Arab sesuai kaidahnya. Maka dari itu pada kesempatan kali ini peneliti bertujuan untuk mengetahui tentang apa saja faktor yang akan mempengaruhi kesalahan berbahasa pada kemampuan berbicara santri dan bagaimana solusi mengatasi permasalahan tersebut. Penelitian ini merupakan penelitian kualitatif yang di lakukan di lingkungan Asrama Putri.

Seperti yang diketahui bahwa pada saat ini banyak pemakai bahasa yang tidak menyadari bahwa bahasa yang telah di gunakan ternyata tidak benar atau masih banyak kesalahan-kesalahan. Dengan adanya analisis kesalahan ini maka diharapkan para pengguna bahasa di tingkat manapun dapat mengurangin kesalahan dalam berbahasanya.

\section{Metode Penelitian}

Penelitian ini berjenis Penelitian Kualitatif sesuai dengan karakteristiknya. Menurut Sugiono, Penelitian Kualitatif sering disebut penelitian naturalistic kerena penelitian dilakukan pada kondisi yang

${ }^{7}$ Citra Resmi, Penerapan Model Pembelajaran Induktif Pada Mata Pelajaran Nahwu. (Yogyakarta, 2012). Hal. 4.

El-Ibtikar Vol 9 No 2 Desember 2020 
alamiah (natural setting), disebut juga penelitian kualitatif, karena data yang terkumpul dan analisisnya bersifat lebih bersifat kualitatif. Penelitian kualitatif adalah penelitian yang berlandaskan pada filsafat postpositivisme, digunakan untuk meneliti pada kondisi obyek yang alamiah. Filsafat postpositivisme sering disebut juga sebagai paradigma intrepretif dan konstruktif, yang memandang realitas sosial sebagai sesuatu yang holistik/utuh, kompleks, dinamis, penuh makna, dan hubungan gejala bersifat interaktif. Penelitian dilakukan pada obyek yang alamiah. Obyek alamiah adalah obyek yang berkembang apa adanya, tidak dimanipulasi oleh peneliti dan kehadiran peneliti tidak begitu mempengaruhi dinamika pada obyek tersebut. ${ }^{8}$ Dalam hal ini peneliti secara langsung terjun kelapangan guna mendapatkan data- data yang diperlukan dalam penelitian yang diambil dari Pondok Moedern AsySyifa Balikpapan.

Sedangkan pendekatan yang digunakan adalah metode kualitatif (Analisis Eror) . Penelitian dengan pendekatan kualitatif menekankan penggambaran dengan kata-kata atau kalimat untuk dipisahkan menurut kategori untuk memperoleh kesimpulan. ${ }^{9}$ Penelitian ini menggunakan pendekatan kualitatif dengan jenis penelitian lapangan (field research). Lexy J. Moleon mengatakan penelitian kualitatif adalah suatu penelitian ilmiah, yang bertujuan untuk memahami suatu fenomena dalam konteks sosial secara alamiah dengan mengedepankan proses interaksi komunikasi yang mendalam antara peneliti dengan fenomena yang diteliti. ${ }^{10}$ Sedangkan, Sugiyono menyimpulkan bahwa penelitian kualitatif adalah penelitian yang digunakan untuk meneliti pada kondisi obyek yang alamiah, dimana peneliti merupakan instrument kunci dalam pengambilan sumber data, pengolahan data dan analisis data, yang mana akan menghasilkan hasil penelitian yang lebih menekankan makna dari pada generalisas. ${ }^{11}$ Dimana mengatakan bahwa dalam penelitian kualitatif kebenaran diyakini bersifat dinamis dan hanya dapat ditemukan dengan

8 Sugiyono, Metode Penelitian Pendidikan Pendekatan Kuantitatif dan Kualitatif, dan RED. (Bandung, CV Alfabeta, 2016). Hal. 14-15.

9 Suharsimi Arikunto, Prosedur Penelitian: Suatu Pendekatan Praktek. (Jakarta: Rineka Cipta, 1998). Hal. 245.

${ }^{10}$ Haris Herdiansyah, Metodologi Penelitian Kualitatif Untuk Ilmu-ilmu Sosial, (Jakarta: Salemba Humanika, 2010). Hal. 9.

${ }^{11}$ Sugiyono, Metode Penelitian..., Hal. 15. 
penelaahan terhadap orang-orang melalui interaksi sosial ${ }^{12}$. Penggunaan jenis penelitian kualitatif dalam penelitian ini diharapkan mampu mengembangkan gaya bahasa yang sempurna pada santri di Pondok Modern Asy-Syifa.

Segala bentuk cara yang digunakan untuk memperoleh data-data yang dibutuhkan dalam sebuah penelitan. Peneliti akan menggunakan teknik empat macam diantaranya, teknik pengumpulan data yaitu berupa observasi, tes, wawancara, dan dokumentasi.

\section{Analisis Kesalahan Bahasa}

Dikemukakan oleh Ellis mendefinisikan analisis kesalahan berbahasa sebagai suatu prosuder yang digunakan oleh para peneliti dan para guru yang mencakup pengumpulan sampel bahasa pelajar, pengenalan kesalahan-kesalahan yang terdapat dalam kesalahan tersebut, pendeskripsian kesalahan-kesalahan itu, pengklasifikasiannya berdasarkan sebab-sebabnya yang telah dihipotesiskan serta pengevaluasinya. Sedangkan Tarigan dan Lilis analisis kesalahan berbahasa adalah prosedur kerja yang biasa digunakan oleh peneliti atau guru bahasa, yang meliputi kegiatan pengumpulan sampel kesalahan, mengidentifikasi kesalahan yang terdapat dalam sampel, menjelaskan kesalahan tersebut mengklasifikasikan kesalahan itu, dan mengevaluasi taraf keseriusan kesalahan itu. ${ }^{13}$

Analisis kesalahan berbahasa bertujuan untuk mendeskripsikan kesalahan pelajar dalam mempelajari bahasa kedua. Dari hasil analisis ini kemudian dijadikan acuan bagi para guru untuk lebih menekankan aspek kebahasaan tertentu yang merupakan wilayah terjadinya kesalahan siswa. Akan tetapi kesalahan yang terjadi pada siswa tidak hanya disebabkan oleh faktor dari dalam diri siswa saja melainkan juga berasal dari berbagai faktor eksternal. Salah satunya adalah kesalahan yang disebabkan oleh kesalahan guru dalam memberikan pengetahuan kepada siswa.

Menurut Ellis (1986) metodologi analisis kesalahan berbahasa meliputi bebrapa tahap, yaitu:

a. Mengumpulkan sampel kesalahan

12 Direktorat Tenaga Kependidikan, Pendekatan, Jenis, dan Metode Penelitian Pendidikan (Jakarta: Departemen Pendidikan Nasional, 2008). Hal. 21.

${ }^{13}$ Wahyu Hanafi Putra, dalam Skripsi Analisis Kesalahan Berbahasa dalam "AlMuhadasah Al-Arabiyyah Al-Yaumiyyah", (Yogyakarta,2015). Hal. 12. 
b. Mengidentifikasi kesalahan

c. Menjelaskan kesalahan

d. Mengklasifikasi kesalahan

e. Mengevaluasi kesalahan. ${ }^{14}$

Sebab dan sumber dari kesalahan berbahasa itu sendiri ada tiga hal yaitu: pertama, Pengaruh bahasa pertama sebagai contoh kalimat أنا أسأل yang sering diucapkan para pelajar adalah satu bentuk kesalahan inferensi dari segi kosakata karena adanya penterjemahan harfiah terhadap "Aku bertanya Kepadamu" dengan menambah kata إلى yang biasa diartikan "ke/kepada". Kalimat yang benar dalam bahasa Arab untuk "Aku bertanya kepadamu "adalah إنا أسألك tanpa penambahan . Kedua, faktor internal bahasa target seperti halnya bahasa Arab yang mempunyai banyak karakteristik yang relatif rumit sehingga tidak mudah untuk dikuasai.

Dikemukakan oleh Tarigan dalam (Hikmayana, 1997:2) bahwa kualitas keterampilan berbahasa seseorang tergantung pada kuantitas kosakata yang diilikinya. Semakin banyak kosakata seseorang, semakin besar pula leterampilan berbahasanya. ${ }^{15}$ Dapat disimpulkan bahwa kurangnya kosa kata siswa juga bisa menjadi faktor penyebab terjadinya kesalahan. Seseorang yang sedikit menguasai kosakatanya akan mengalami kesulitan dan menentukan kata yang tidak tepat untuk menyampaikan gagasannya. Kurangnya kosakata disebabkan oleh kebiasaan membaca siswa yang rendah. Ketiga, evaluasi kesalahan berbahasa dimana setiap ada kesalahan pasti ada evaluasi. Evaluasi merupakan komponen yang penting dalam pendidikan terutama evaluasi pembelajaran. Penting karena kegiatan evaluasi paling tidak untuk mengetahui. Pertama, keberhasilan pembelajaran yang telah dilakukan. Kedua, kemampuan peserta didik dalam memahami materi pembelajaran. Ketiga, sebagai feedback bagi guru/dosen untuk memperbaiki kegiatan pembelajaran yang telah dilakukan. Evaluasi tersebut sangat beperan penting dalam kegiatan analisis kesalahan bebahasa. Penting disebut

${ }^{14}$ Wahyu Hanafi Putra, dalam Skripsi Analisis Kesalahan Berbahasa dalam "AlMuhadasah Al-Arabiyyah Al-Yaumiyyah", (Yogyakarta: 2015). Hal. 15.

15 Fina Sa'adah, "Analisis kesalahan Berbahasa dan pertanyaan dalam pembelajaran bahasa asing", dalam Jurnal Studi Islam dan Sosial, No. 1, Vol. 14, 2012 
karena dengan adanya sistem evaluasi yang baik maka akan mampu merekontruksi pembelajran bahasa yang lebih baik kedepannya. ${ }^{16}$

\section{Pembelajaran Nahwu dan Sharaf (Tata Bahasa)}

Seseorang akan dikatakan mampu apabila ia telah mampu menerapkan kaidah-kaidah dalam ilmu nahwu dan sharaf. ilmu nahwu dan ilmu shorof dianggap dengan dua ilmu yang terpisah, dimana ilmu nahwu membahas susunan dan kondisi akhir kalimat. Ilmu sharaf membahas perubahan kata dari satu bentuk kebentuk yang lain. Ilmu nahwu lebih terfokus bagaimana suatu kalimat itu tersusun serta aturanaturan yang terkait seperti harakat, letak kata, danbentuk kata. Sebagai contoh kalimat:

\section{zجَلَسنَ زَيدّ}

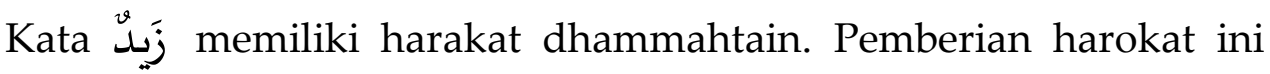
tidak dilakukan dengan sembarangan melainkan ada aturan yang baku. Seseorang tidak bisa memberikan harakat dhammah, kasrah, kasratain tanpa melihat kondisi kalimat yang ada. Kemudian kata زَ زَدِ yang merupakan subjek lebih diakhirkan ketimbang kata kerja جَلَسَpadahal didalam tata bahasa indonesia subjek lebih dulu daripada predikat (kata kerja). Kemudian dari sisi pemilihan kata kerja sendiri ada aturan khusus tentang hal tersebut. Contoh yang duduk seorang wanita, maka kata kerja yang digunakan menjadi:

$$
\text { hindun telah duduk جَلَسَت هِند }
$$

Semua hal yang diatas telah dijelaskan dengan secara terperinci dengan ilmu nahwu. Adapaun sharaf tidak membahas hal tersebut, melainkan fokus kepada aturan perubahan kata dari satu bentuk kebentuk yang lain. Ilmu sharaf membahas bagaimana kata جَلَسن berubah menjadi dan bentuk lainnya. Contohnya jika yang duduk adalah kami maka kata kerjanya menjadi جَلَسـنَا perubahan kata ini beserta rumusrumus perubahannya dibahas secara mendalam di ilmu sharaf. ${ }^{17}$

16 Wahyu Hanafi Putra, dalam Skripsi ..., Hal. 17.

${ }^{17}$ Abu Razin dan Ummu Razin, Ilmu Sharaf untuk Pemula, (Jakarta: Maktabah, 2010). Hal. 1-2. 
Ilmu nahwu dan ilmu sharaf sangat penting untuk dikuasai bagi orang yang mempelajari bahasa Arab. Oleh karena itu, ilmu nahwu dan ilmu sharaf disebut dengan ilmu alat, dimana ilmu ini harus memahami kalimat bahasa Arab.

Contoh penyusunan kalimat يَذهَبُ زَيدّ إلَىلى المَدرَسَسَة zaid sedang pergi ke sekolah. Kalimat ini memiliki unsur tiga penyusunan. Pertama, Fiil (kata kerja) kedua, isim (kata benda) ketiga, huruf Arab yang memiliki makna.

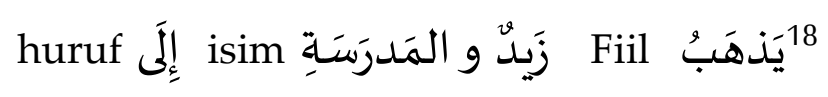

kesalahan gaya bahasa dalam percakapan yang diucapkan seperti :

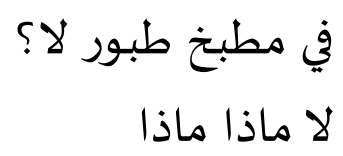

contoh penyusunan kalimat yang benar adalah :

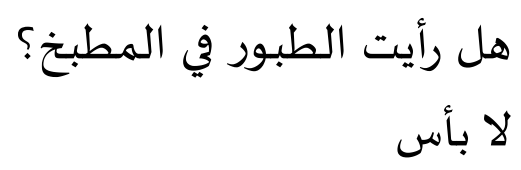

Kesalahan gaya berbahasa dalam percakapan:

yang artinya “kemana ayahmu akan pergi” kata yang digaris bawahi merupakan kata yang salah dalam penggunaan tata bahasa yang baik. Berasal dari kata "abun" adalah salah satu asma'ul khomsah, yang jika posisi rofa' harus ditambah "alif" dan kalo "jer" ditambah "ya'". Itu sebagai fai'il dari fi'il "yadzhabu", dan fa'il posisi "rofa'”. Maka ditambah "wawu" jadi yang pas ialah إلى أين يذهب أبوك

artinya “apakah kamu menginginkan minum” kata yang digaris bawah merupakan kata yang salah dalam penggunaan tata bahasa yang baik. Kata yang diagris bawahi merupakan tanda dommah tayin, yang harusnya menjadi fathah tanwin. Karena posisinya sebagai maf'ul bih. Dimana tandanya adalah i'rob nasob dengan harokat fathah dengan tanwin, karena dia "nakhiroh". Maka posisi kalimat yang pas ialah هل تريد شَبِا

${ }^{18}$ Abu Razin dan Ummu Razin, Ilmu Sharaf untuk Pemula ...., Hal. 3. 


\section{Keterampilan Berbicara}

Dikemukakan oleh Tarigan, berbicara merupakan kombinasi faktorfaktorfisikk, psiologis, neurologis, semantik dan linguistik secara luas sehingga dapat dianggap sebagai alat manusia yang paling penting bagi kontrol sosial. Maharah kalam secara bahasa sepadan dengan istilah speaking skill dalam bahasa inggris yang bisa diartikan sebagai keterampilan berbicara.

Selain itu juga berbicara merupakan suatu bentuk perilaku manusia yang memanfaatkan faktor-faktor fisik, psikologis semantik, dan lnguistik sedemikian ekstensif, secara luas sehingga dapat dianggap dianggap sebagai alat manusia yang paling penting bagi kontrol sosial.

Dengan demikian, keterampilan bahasa ialah kemampuan seseorang untuk mengucapkan artikulasi bunyi-bunyi Arab, atau kata-kata dengan aturan-aturan kebahasaan (qowaid nahwiyyah) tertentu untuk menyampaikan ide-ide dan perasaan. Berbcara dengan menggunakan bunyi-bunyi secara benar yang dikeluarkan melalui makhrijul huruf yang telah menjadi pakar bahasa.

Keterampialn berbicara ini dapat dicapai melalui beberapa latihan seperti praktek dari apa yang didengar secara pasif dalam latihan mendengar. Sebab tanpa latihan lisan secara intensif, maka sangat sulit bagi peserta didik untuk mencapai penguasaan bahasa Arab secara sempurna. Salah satu teknik untuk mencapai kemampuan keterampilan berbahasa lisan secara efektif- maksudnya disini dari yang sederhana sampai kepada yang rumit misal dengan menggunakan latihan pola kalimat (al-tamarin ni al-namazij), istilah lain yang lebih populer adalah (pattern drill). ${ }^{19}$

Problemtika pembelajaran maharah kalam terhadap siswa ini terjadi akibat faktor fsiologis, faktor psiologis, faktor pendekatan belajar seperti metode dalam melakukan kegiatan pembelajaran tersebut.

\section{Hasil Penelitian}

Dalam penelitian ini langkah awal yang dilakukan oleh penulis ialah observasi. Observasi adalah pengamatan dan pencatatan secara sistematik terhadap gejala yang tampak pada objek penelitian. ${ }^{20}$ Dasi hasil observasi

19 Zulhannan, Teknik Pembelajaran Bahasa Arab Teraktif, cet.2, (Jakarta: PT RajaGrafindo,2015). Hal. 77.

${ }^{20}$ Margono, Metodologi Penelitian Pendidikan, (Jakarta: Rineka Cipta, 2007). Hal. 158. 
ini didapat bahwa terdapat santri yang sedang berkomunikasi dilapangan rayon putri.

Setelah melakukan observasi, langkah selanjutnya ialah peneliti melakukan wawancara terhadap santri dan pimpinan pondok modern asy-syifa balikpapan tersebut. Teknik melakukan wawancara ialah alat mengumpulkan informasi dengan cara mengajukan sejumlah pertanyaan lisan untuk dijawab dengan lisan juga dengan cara bertatap muka agar mendapatkan informasi yang tepat dan objektif.

Dari hasil wawancara tersebut mengenai analisis kesalahan berbagasa Arab (tinjauan nahwu) pada kemampuan berbicara siswa di pondok modern asy-syifa adalah dengan Cara pendidik mengajarkan santri agar santri dapat mengaplikasikannya dikehidupan sehari-hari yakni dengan cara mengajarkannya berurutan dari yang mudah ke yang sulit, dari yang konkret ke yang abstrak. Kemudian memberikan contohcontoh yang fungsional sesuai dengan kemampuan siswa sehingga mereka mampu menerapkannya. Adapun strategi-strategi khusus agar mudah diterapkan oleh santri, sebenarnya strateginya sama dengan strategi pada umumnya, hanya saja diberikan penguatan-penguatan contoh-contoh dan praktek. Lebih penekanan pada drill dengan kata dan kalimat fungsional sehari-hari. Faktor-faktor penyebab santri dalam pengucapan bahasa Arab yakni ada faktor internel, dimana faktor yang merupakan kurangnya pemahaman siswa dalam penerapan dikomunikasi aktif, atau sebenarnya mereka faham hanya saja prakteknya kurang mampu implementasi nahwunya dalam berbicara, tidak merasa percaya diri dan takut salah. Cara pendidik untuk meningkatkan pemahaman santri agar santri cepat memahami pelajaran bahasa Arab terutama nahwu ialah lebih pada memberikan pengetahuan, drill, dimotivasi agar tidak takut salah, karena bicara itu yang penting lawan bicara bisa faham, tidak perlu takut salah dari segi implementasi nahwunya. Selama ada kesepakatan dan peraturan bahwa siswa harus bicara bahasa Arab. Maka akan mudah sedikit memaksa siswa untuk bicara meskipun salah nahwunya, akan tetapi yang penting bicara bahasa Arab dan lawan bicara faham.

Dari pembahasan mengenai pengjaran bahasa Arab dipondok modern asy-syifa ialah kita mengenal dari awal bagaimana tujuan dan latar belakang pembelajaran bahasa Arab. Karna pondok ini 
mengiinginkan santri agar bisa memahami al-qurna karna al-quran memakai bahasa Arab, yang kedua memberikan kunci kepada santri agar mereka didalam memahami kitab itu tidak bergantung pada terjemahan saja. Sebab kalau bergantung pada terjemahan saja itu tidak lengkap. Karna ada kata-kata bahasa Arab itu tidak bisa diterjemahkan ke bahasa indonesia akan tetapi harus dipahami kalo kita bisa berbahasa Arab artinya pemahamannya itu bisa sempurna daripada hanya liat terjemah. Latar belakangnya artinya melihat situasi masyarakat yang sudah banyak tidak menyukai bahasa Arab dan juga banyak memahami alquran ataupun kitab-kita itu hanya dari terjemahan saja. Metode yang dilakukan ialah metode yang sudah teruji, yakni metode langsung yang saat ini seiring dengan perkembangangan jaman bisa dilakukan dengan memakai alat komunikasi seperti slide, video, lagu-lagu dan lain sebagainya.

Adapun faktor pendukung dan penghambat santri dalam melakukan berbahasa Arab:

1. Faktor Penghambat

Faktor penghambat yang paling utama ialah karna malas, tapi itu dari pribadi masing-masing santri. Untuk faktor diluar sementara masih belum mampu menyiapkan alat komunkasi atau media yang terbaru yang seharusnya itu harus ada.

2. Faktor Pendukung

Faktor pendukung yang pertama semua ustad ustadzah yang berada didalam memang lulusan pondok pesantren. Kemudian, yang kedua program dan kegiatan memang diatur secara sengaja dengan menggunakan bahasa terutama bahasa Arab.

\section{Kesimpulan}

Hasil penelitian ini menegaskan bahwa kesalahan berbahasa Arab pada kemampuan berbicara bahasa Arab siswa di pondok modern asySyifa antara lain terletak pada kesalahan penyebutan, pembiasaan dalam penyebutan, kesalahan dalam penentuan harakat akhir. Kesalahankesalahan berbahasa Arab tersebut disebabkan beberapa faktor antara lain, penguasaan kaidah, pengunan kata yang kurang tepat, ketidak telitian dalam berbicara, kurangnya motivasi berbicara dan kurangnya kosa kata santri.

Upaya yang dilakukan untuk mengatasi kesalahan penggunaan berbahasa Arab antara lain menerapkan fase-fase pendekatan proses 
dalam pembelajaran berbicara, meningkatkan penguasaan kaidah kebahasaan santri dengan cara membaca, ustadz dan ustadzah harus berperan aktif dalam memotivasi santri untuk sering berlatih berpidato dan mengikutsertakan lomba cerdas cermat.

Hal-hal yang dapat dilakukan guru pondok untuk meminimalisir kesalahan berbahasa hasil observasi antara lain: Pertama, santri diharapkan lebih memperhatikan saat ustad maupun ustadzah sedang menjelaskan materi; Kedua, ustad maupun ustadzah senantiasa membenarkan kesalahan berbahasa santri dengan analisis pembahasannya. Baik ustadz maupun ustadzah harus selalu memperluas kosakata dan memberi contoh terkait dengan pemakaian bahasa Arab yang baik dan benar, baik secara lisan maupun secara tertulis; dan ketiga, pihak pondok hendaknya melengkapi sumber pustaka terkait yang memadai misalnya buku-buku tentang bahasa Arab yang benar.

\section{Daftar Pustaka}

Izzan, Ahmad. 2015. Metodologi Pembelajaran Bahasa Arab, Bandung: Humaniora.

Wiratno, Tri dan Santosa, Riyadi. "Bahasa,Fungsi Bahasa, dan Konteks Sosial", dalam Modul Pengantar Linguistik Umum,Bing4214/Modul,1. Rohman, Fathur. 2015. Metodologi Pembelajaran Bahasa Arab, Jatim: Madani. Muna, Wa. 2011. Metodologi Pembelajaran Bahasa Arab, Yogyakarta: Penerbit Teras.

Azra, Azyumardi. 1999 Esei-Esei intelektual muslim dan Pendidikan Islam, Jakarta: Wacana Ilmu.

Johan, Muhammad Gio dan Simatupang JR Yusrawati. 2017. Analisis Kesalahan Berbahasa Indonesia Secara Sintaktis dalam Proses Diskusi, dalam Jurnal Visipena no.2, Vol.8.

Resmi, Citra. 2012. Penerapan Model Pembelajaran Induktif Pada Mata Pelajaran Nahwu, Yogyakarta.

Sugiyono. 2016. Metode Penelitian Pendidikan Pendekatan Kuantitatif dan Kualitatif, dan RED, Bandung, CV Alfabeta.

Arikunto, Suharsim.1998. Prosedur Penelitian: Suatu Pendekatan Praktek, Jakarta: Rineka Cipta.

Herdiansyah, Haris. 2010. Metodologi Penelitian Kualitatif Untuk Ilmu-ilmu Sosial, Jakarta: Salemba Humanika. 
Putra, Hanafi Wahyu. 2015. dalam Skripsi Analisis Kesalahan Berbahasa dalam "Al-Muhadasah Al-Arabiyyah Al-Yaumiyyah", Yogyakarta.

Sa'adah, Fina. 2012. Analisis kesalahan Berbahasa dan pertanyaan dalam pembelajaran bahasa asing", dalam Jurnal Studi Islam dan Sosial, No. 1, Vol. 14.

Razin, Abu dan Razin Ummu. 2010. Ilmu Sharaf untuk Pemula, Jakarta: Maktabah.

Zulhannan. 2015. Teknik Pembelajaran Bahasa Arab Teraktif. Jakarta: PT RajaGrafindo.

Margono. 2007. Metodologi Penelitian Pendidikan, Jakarta: Rineka Cipta. 